\title{
Research on Import and Export Trade Based on China's FDI to Central Asian Countries
}

\begin{abstract}
Based on China's FDI and import and export trade data with Central Asian countries from 2011 to 2019, this article studies whether and how China's investment in Central Asian countries affects import and export trade. The analysis methods of this article include descriptive statistics and empirical analysis, which are used to describe the relationship and trend of China's FDI to Central Asian countries and import and export trade. In the empirical analysis, this paper chooses the panel data linear regression model. Through regression analysis of FDI-import and FDI-export, we test the impact of China's FDI changes in Central Asian countries on import and export trade. The research results show that China's FDI to Central Asian countries has a significant trade promotion effect on import and export trade, and the growth of China's FDI to Central Asian countries will effectively drive the growth of import and export trade. China's FDI in Kazakhstan and Uzbekistan has a strong trade creation effect. China's FDI in Kyrgyzstan and Tajikistan has a strong trade substitution effect. China should strengthen economic and trade cooperation with Central Asian countries and expand the scale of FDI. Each country should reduce trade barriers, expand investment fields, and provide favorable policy support for expanding the scale of FDI.
\end{abstract}

Keywords: China, Central Asian countries, FDI, Import and export trade, Panel data linear regression

\section{Introduction}

As a major foreign investment country and a major foreign trade country in the world, the impact of China's FDI changes on import and export trade has attracted much attention. Central Asian countries are located in the center of Asia, connecting China and the European continent. China and Central Asian countries have short trade distances, low costs, and good import and export trade conditions. In recent years, China's direct investment in Central Asian countries has continued to expand. According to "2019 statistical bulletin of china 's outward foreign direct investment", China's FDI in Central Asian countries has risen from US\$4.033 billion in 2011 to US $\$ 14.223$ billion in 2019. China has become an important economic partner of Central Asian countries. China is also a major foreign trade country of Central Asian countries. According to the China Statistical Yearbook, the import and export trade volume between China and Central Asian countries has risen from 39.65 billion U.S. dollars in 2011 to 46.35 billion U.S. dollars in 2019. After the COVID-19, as the global economy recovers, the scale of investment and trade between China and Central Asian countries will further expand. This will not only promote the economic development of all parties, but also help strengthen the trade cooperation between China and Central Asian countries. Therefore, this research provides a direction for the future development of FDI and import and export trade between China and Central Asian countries, and has practical significance for the growth of import and export trade and economic cooperation between China and Central Asian countries.

\subsection{Problem Statement}

With the development of the economy and the stability of Central Asia, China's FDI and the scale of imports and exports to Central Asian countries are showing an upward trend. Among 


\author{
Zhang Lingzhi \\ Research on Import and Export Trade Based on China's FDI to Central Asian Countries
}

the factors that promote economic growth, FDI and import and export trade are both very important. Whether FDI can drive import and export trade, and how much it can drive, is very necessary to promote the economic growth of China and Central Asian countries.

\title{
1.2 Aim of the Study
}

Based on empirical analysis, this paper studies the foreign trade effects of China's FDI in Central Asian countries. Different from previous studies, this article uses descriptive statistics to show the relationship between China's FDI and import and export trade in Central Asian countries. And with the help of econometric methods, two sets of panel data linear regression were performed on FDI-imports and FDI-exports to test the effects and trends of China's FDI and import and export trade relations in Central Asian countries. This article judges the effect of FDI on import and export trade through the elastic coefficient of FDI's influence on import and export trade, and draws credible conclusions.

\section{Literature Review}

\subsection{Theoretical Analysis of the Impact of FDI on Import and Export Trade}

Regarding the impact of FDI on import and export trade, scholars have done a lot of theoretical analysis, with different conclusions. Mundell (1957) pointed out that there is a mutual substitution relationship between FDI and import and export trade, which means that the increase in FDI will lead to a decrease in import and export trade. With the development of international trade, substitution theory cannot explain FDI's promotion of trade development. Japanese scholar Kiyoshi Kojima (1987), based on the theory of comparative advantage, proposed that FDI and trade in industries that are at a disadvantage in their own country are complementary. With the increasingly close global economic cooperation, the relationship between FDI and import and export trade not only shows substitution or complementarity, but also shows a more complex dynamic interactive relationship. Michael and Bedassa (2004) believe that the relationship between FDI and trade is affected by the maturity of the host country's market. The higher the maturity of the host country's market, the weaker the complementary relationship between FDI and trade.

\subsection{Empirical Research on the Impact of FDI on Import and Export Trade}

On the basis of the current basic theoretical research, scholars have begun to use different empirical methods to analyze the impact of FDI on import and export trade. Chinese scholars are more inclined to focus on the relationship between FDI and trade from a specific perspective, industry or country, and mainly analyze the impact of FDI on trade through methods such as gravity models and vector autoregressive models. Based on the gravity model, Xiang Benwu (2006) selected panel data of China's direct investment and imports and exports from 50 countries or regions from 1999 to 2001 to conduct an empirical analysis. The results show that China's FDI has no significant substitution effect on imports and exports, but a significant promotion effect. Lai Shicheng and Zhong Wei (2011) selected panel data on trade and direct investment between China and ASEAN countries from 2003 to 2009, and used the generalized least squares method for regression analysis. The results showed that China's FDI and trade with ASEAN have a two-way causal relationship, and there is a relationship between them. The relationship of mutual substitution and complementation. Jiang Wei and Fu Yuding (2014) selected the panel data of China's two-way FDI from 1982 to 2012 and used the Var cointegration model to conduct empirical analysis. The results show that China's FDI has obvious export creation effects and import substitution effects. Regarding the issue of China's FDI in Central Asian countries, Yang Dianzhong (2012) made a detailed analysis of the industrial distribution of China's FDI in Central Asian countries. China's FDI in Central Asian countries is mainly concentrated in the mining, construction and trade service industries; for Kyrgyzstan The FDI of China is mainly based on agricultural breeding, agricultural products and food 


\section{Zhang Lingzhi \\ Research on Import and Export Trade Based on China's FDI to Central Asian Countries}

processing industries. It is recommended that China diversify its FDI structure in Central Asian countries and determine the choice of investment industries based on local conditions. Qin Fangming (2012) and Shi Jinfang (2015) believe that in promoting the development of China's FDI in Central Asia, it is necessary to give full play to the role of the Shanghai Cooperation Organization and provide support for improving the regional investment environment. Zhu Zhiming (2015) used the Cobb-Douglas production function to construct a generalized least squares method, and measured the impact of China's FDI on the economic growth of Central Asian countries based on panel data from 2003 to 2013. The results show that China's FDI has a significant overall impact on the economic growth of Central Asian countries, but the degree of impact varies among countries. It is proposed that China should transform its cooperation model in terms of assessment of the investment environment of Central Asian countries, selection of investment cooperation targets, investment fields and cooperation methods. Wang Guoting and Ren Rongming (2015) used the panel data of China and Central Asia from 2003 to 2013 to analyze the influencing factors of China's direct investment in Central Asia and found that China's FDI in Central Asia was mainly caused by cheap labor, a vast market and abundant resources. In the empirical analysis, due to the different data subjects and analysis methods of the selected samples, the conclusions obtained are also inconsistent. However, current scholars believe that the relationship between trade and investment mainly depends on the choice of the main body of empirical analysis, and the trade effects of FDI show different results.

From the perspective of the main body of research, there are few Central Asian countries involved. In the research on FDI and import and export trade between China and Central Asian countries, there are few empirical studies, most of which are concentrated on the investment environment evaluation in Central Asia, the distribution of FDI in industries, and the pull of FDI on GDP. From the perspective of the foreign trade effect of FDI, this paper studies the extent of China's FDI in Central Asian countries' impact on import and export trade. In order to get a more credible conclusion, this paper uses the panel data linear regression model to determine the two elasticity coefficients of FDI to import trade and FDI to export trade.

\section{Research Methodology}

The study used statistical methods and situational analysis. The empirical research method is a linear regression of fixed effects based on panel data. Two models are established to test the relationship between FDI and import trade and export trade. The tools have been used in various combinations at different stages of the research, which allowed to ensure the scientific reliability of the final results.

Model 1:

In IMij = a1 + $\beta 1$ In FDIij + e1

$\mathrm{IM}=$ Import

FDI $=$ Foreign Direct Investment

Model 2:

In EXij $=a 2+\beta 2 \ln$ FDIij $+e 2$

$E X=$ Export

FDI $=$ Foreign Direct Investment 


\author{
Zhang Lingzhi \\ Research on Import and Export Trade Based on China's FDI to Central Asian Countries
}

In the formula, $i$ represents a certain country that China directly invested in Central Asia, and $j$ represents a certain year of observation. $a 1$ and $a 2$ are intercept terms. $\beta 1$ and $\beta 2$ represent the FDI elasticity coefficients of import trade and export trade. e1 and e2 are random disturbance terms.

\title{
4. Data Analysis and Interpretation
}

\subsection{The Status Quo of China's FDI in Central Asian Countries}

China's FDI to Central Asian countries has generally shown rapid growth. After 2011, it entered a stage of rapid development. In 2019, China's FDI to Central Asian countries reached US\$14 billion, an increase of 3.5 times from the US\$4 billion in 2011 . However, the distribution of China's FDI in Central Asian countries is quite different, mainly concentrated in Kazakhstan, which accounts for $50 \%$ of China's investment in Central Asian countries. The "World Investment Report" published by the United Nations divides FDI motivations into market-seeking, resourceseeking, efficiency-seeking and technology-seeking motives. China's FDI in Central Asian countries is mainly market-seeking and resource-seeking. These two investment opportunities drive China's imports of energy and mineral resources from Central Asian countries, and increase China's exports of machinery and light industrial products.

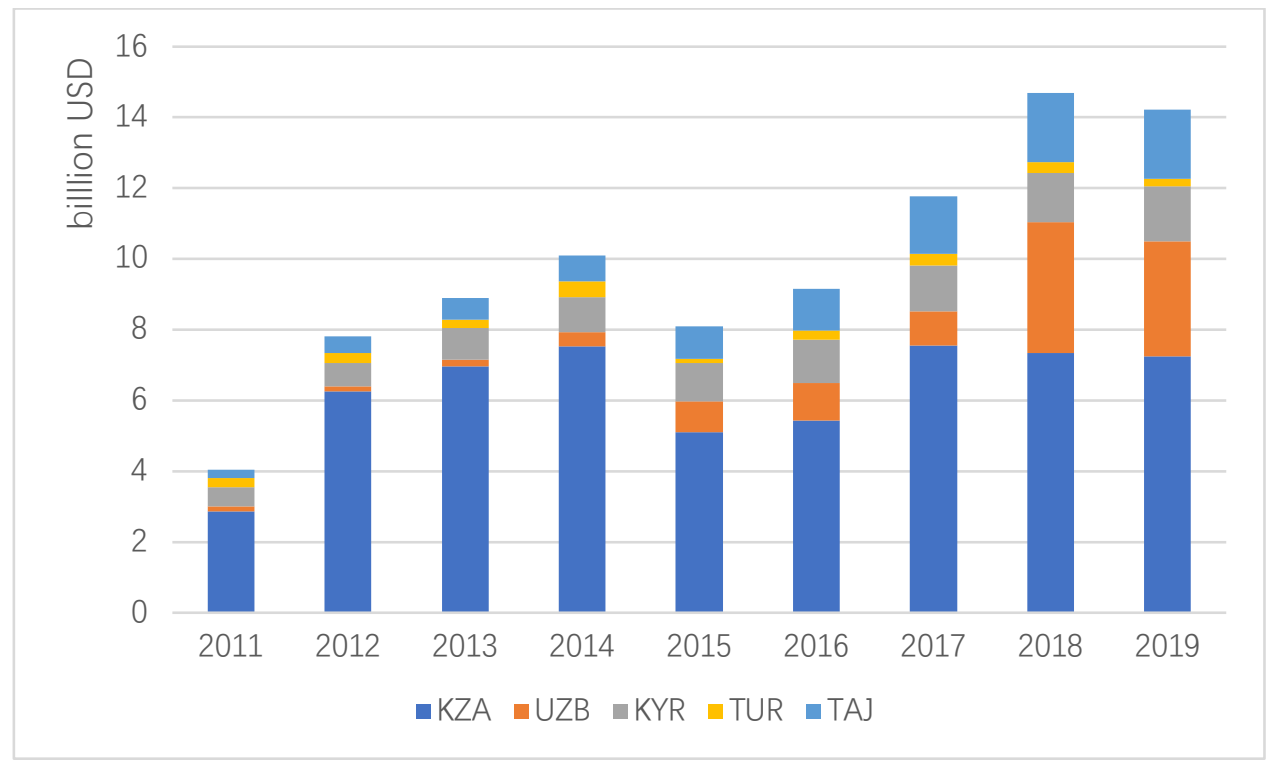

Figure 1: China's FDI to Central Asian countries from 2011 to 2019

Data Sources: 2019 statistical bulletin of china 's outward foreign direct investment

\subsection{China's Foreign Trade Status with Central Asian Countries}

The trade between China and Central Asian countries is showing an increasing trend. In 2019, the trade volume between China and Central Asian countries reached 46.35 billion U.S. dollars, 1.2 times the trade volume in 2011. China's imports to Central Asian countries are mainly concentrated in Kazakhstan, Uzbekistan and Turkmenistan, these three countries have rich oil and natural gas resources. The volume of import trade with Kazakhstan is showing a downward trend. In 2011, China and Turkmenistan reached an agreement on natural gas supply, which increased Turkmenistan's energy export trade volume. In 2014, Turkmenistan's energy export trade with China exceeded that of Kazakhstan. 


\section{Zhang Lingzhi}

Research on Import and Export Trade Based on China's FDI to Central Asian Countries

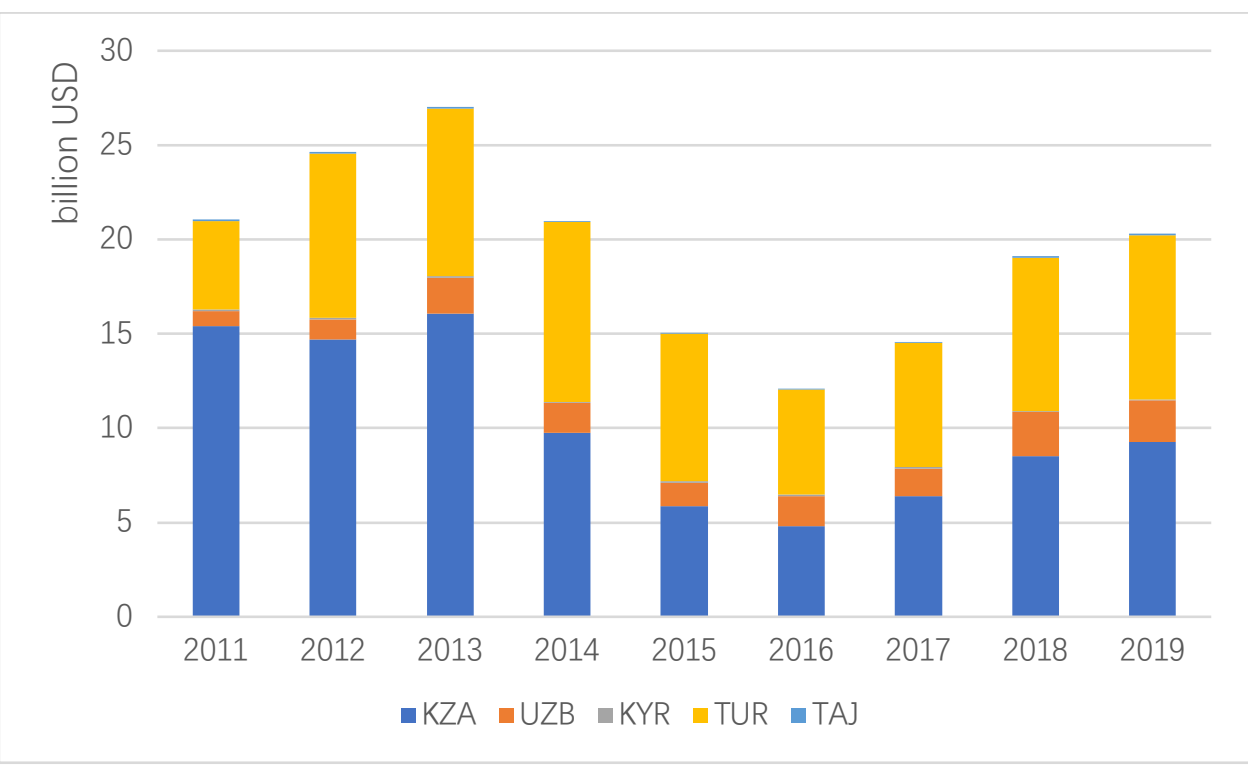

Figure 2: China's import trade to Central Asian countries from 2011 to 2019

Data Sources: China Statistical Yearbook (2012-2020)

China's exports to Central Asian countries from 2011 to 2019 are ranked in the order of Kazakhstan, Kyrgyzstan, Uzbekistan, Tajikistan, and Turkmenistan. China's exports to Kazakhstan, Uzbekistan and Kyrgyzstan are showing an increasing trend. Compared with the other three countries, China's exports to Tajikistan and Turkmenistan are smaller in scale and have a lower proportion.

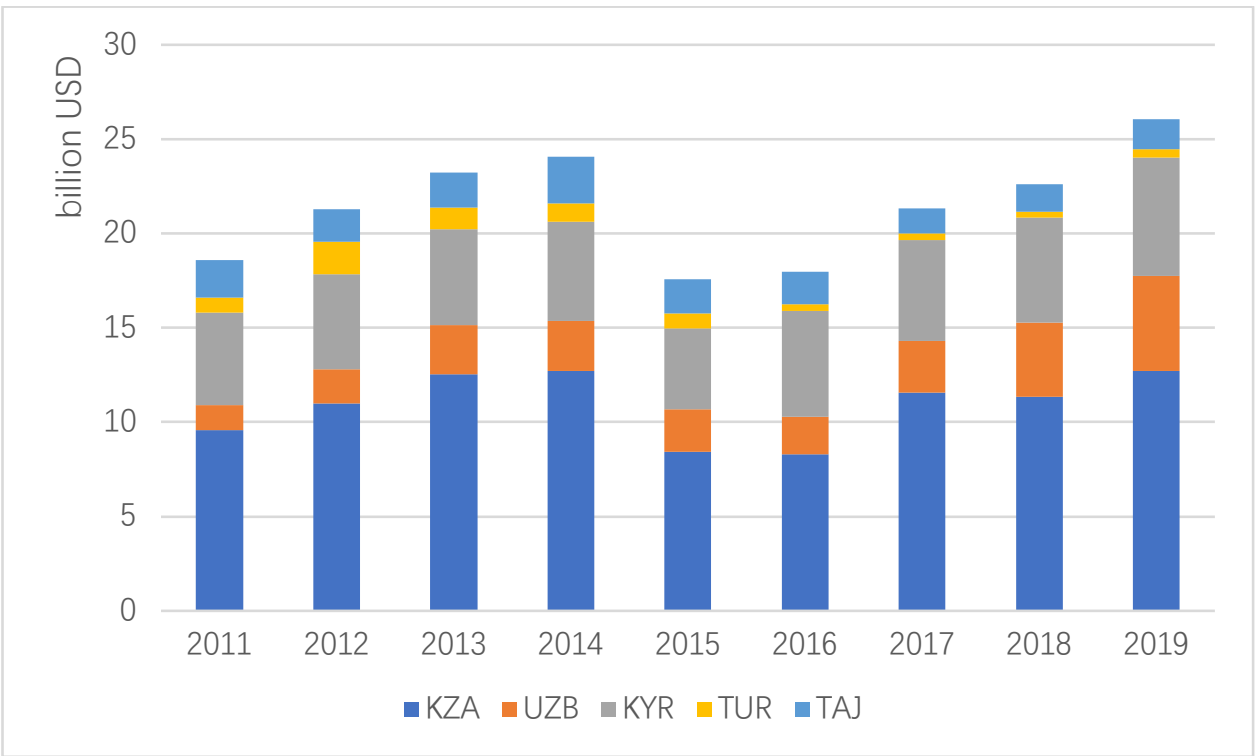

Figure 3: China's export trade to Central Asian countries from 2011 to 2019

Data Sources: China Statistical Yearbook (2012-2020)

\subsection{An Empirical Analysis of the Impact of China's FDI Import and Export Trade on Central Asian Countries}

Analyzing the impact of FDI on import and export trade will help to further understand the relevance of FDI and import and export trade, and provide policy reference for economic and trade cooperation between China and Central Asian countries. 


\author{
Zhang Lingzhi \\ Research on Import and Export Trade Based on China's FDI to Central Asian Countries
}

\title{
4.3.1 Data Variable Selection and Data Description
}

Based on the panel data of FDI and import and export trade in China and Central Asian countries from 2011 to 2019, this paper conducts an empirical analysis of the relationship between FDI and import and export trade. The variables of the model are China's FDI (year-end balance), export trade value (EX), and import trade value (IM) to Central Asian countries. Kazakhstan (KZA), Uzbekistan (UZB), Kyrgyzstan (KYR), Turkmenistan (TUR), and Tajikistan (TAJ) are used as cross-sectional data. Variable data mainly come from the "China Statistical Yearbook" (20122020) and the "2019 Statistical Bulletin of China's Foreign Direct Investment". According to the needs of the model, take the natural logarithm of the variable data.

\subsubsection{Model Setting}

In order to reflect the impact of China's FDI in Central Asia on import and export trade, this article mainly examines whether China's FDI in Central Asian countries affects the import and export trade of China and Central Asian countries, and how much the impact is. This paper uses the import trade value (IM) and export trade value (EX) of China and Central Asian countries as dependent variables, and China's FDI to Central Asian countries as independent variables to establish two regression models:

\section{Model 1:}

The regression model of the impact of China's FDI in Central Asian countries on China's import trade:

$\ln \mathrm{IM}_{\mathrm{ij}}=\mathrm{a}_{1}+\beta_{1} \ln \mathrm{FDI}_{\mathrm{ij}}+\mathrm{e}_{1}$

\section{Model 2:}

The regression model of the impact of China's FDI in Central Asian countries on China's export trade:

$\ln E X_{i j}=a_{2}+\beta_{2} \ln F D I_{i j}+e_{2}$

In the formula, $\mathrm{i}$ represents a certain country that China directly invested in Central Asia, and $\mathrm{j}$ represents a certain year of observation. $a_{1}$ and $a_{2}$ are intercept terms. For the double logarithmic model, the economic significance of the variable coefficients is very clear. $\beta_{1}$ and $\beta_{2}$ represent the FDI elasticity coefficients of import trade and export trade, and $e_{1}$ and $e_{2}$ are random disturbance terms.

\subsubsection{Model Testing}

Due to the difference in the scale of China's imports and exports and FDI among Central Asian countries, this paper performs a fixed effect linear regression on panel data. The regression results of the impact of China's FDI on Central Asian countries on import and export trade are shown in Table 1.

Table 1: Test results of China's import and export trade impact of FDI in Central Asian countries

\begin{tabular}{|c|c|c|}
\hline country & model 1 & model 2 \\
\hline \multirow{2}{*}{ KZA } & $0.4083^{* * *}$ & $0.3455^{* *}$ \\
& $(0.0935)$ & $(0.1555)$ \\
\hline
\end{tabular}




\section{Zhang Lingzhi}

Research on Import and Export Trade Based on China's FDI to Central Asian Countries

\begin{tabular}{|c|c|c|}
\hline UZB & $\begin{array}{c}0.1965^{* *} \\
(0.0736)\end{array}$ & $\begin{array}{l}0.2581^{* * *} \\
(0.0740)\end{array}$ \\
\hline \multirow{2}{*}{ KYR } & $-0.6708^{* * *}$ & $-0.1641^{* *}$ \\
& $(0.0817)$ & $(0.0746)$ \\
\hline \multirow{2}{*}{ TUR } & 0.0628 & -0.0583 \\
& $(0.2729)$ & $(0.6864)$ \\
\hline \multirow{2}{*}{ TAJ } & $-0.4505^{* * *}$ & $0.1645^{* * *}$ \\
& $(0.1470)$ & $(0.0446)$ \\
\hline \multirow{2}{*}{ Central Asia } & $0.3361^{* * *}$ & $0.2188^{*}$ \\
& $(0.1069)$ & $(0.1056)$ \\
\hline
\end{tabular}

Note: $*, * *, * * *$ indicate the statistical significance level of $10 \%, 5 \%$ and $1 \%$. The data in parentheses are standard errors.

\subsubsection{Result Analysis}

China's FDI to Central Asia is a trade creation type, and the regression analysis results passed the $5 \%$ significance test. For every $1 \%$ increase in China's FDI to Central Asia, China's import trade and export trade to Central Asia increase by $0.34 \%$ and $0.22 \%$ respectively. Generally speaking, China's FDI in Central Asia has a significant promotion effect on import and export trade.

From the perspective of each country, with the exception of Turkmenistan, the regression results of China's FDI and import and export trade to Kazakhstan, Uzbekistan, Kyrgyzstan, and Tajikistan have all passed the 5\% significance test. From the economic sense of the regression results, for every $1 \%$ increase in China's FDI to Kazakhstan and Uzbekistan, the import trade volume will increase by $0.41 \%$ and $0.19 \%$, and the export trade volume will increase $0.35 \%$, $0.26 \%$. For every $1 \%$ increase in China's FDI to Kyrgyzstan, the volume of import trade and export trade will decrease by $0.67 \%$ and $0.16 \%$ respectively. For every $1 \%$ increase in China's FDI to Tajikistan, the import trade volume will decrease by $0.45 \%$ and the export trade volume will increase by $0.16 \%$.

Table 2: Empirical analysis of the impact of China's FDI in Central Asian countries on import and export trade

\begin{tabular}{|c|c|c|c|c|}
\hline country & Coef. $\left(\boldsymbol{\beta}_{\mathbf{1}}\right)$ & Import effect & Coef. $\left(\boldsymbol{\beta}_{\mathbf{2}}\right)$ & Export effect \\
\hline KZA & 0.4083 & creation & 0.3455 & creation \\
\hline UZB & 0.1965 & creation & 0.2581 & creation \\
\hline KYR & -0.6708 & substitution & -0.1641 & substitution \\
\hline TUR & $/$ & $/$ & $/$ & $/$ \\
\hline TAJ & -0.4505 & substitution & 0.1645 & creation \\
\hline Central Asia & 0.3361 & creation & 0.2188 & creation \\
\hline
\end{tabular}

\section{Conclusion and Recommendations}

1. This article studies the foreign trade effects of China's FDI in Central Asian countries. In order to test the impact of China's FDI in Central Asian countries on import and export trade, two sets of panel data linear regression were performed on FDI-import and FDI-export, and the elastic coefficient of FDI's impact on import and export trade was obtained. The elasticity coefficient is used to illustrate the import and export trade effects of China's FDI in Central Asia and the five countries. 
2. China's FDI in Central Asia has a trade creation effect and has a significant role in promoting import and export trade. The elasticity of FDI to import trade and export trade is 0.34 and 0.22 respectively, that is, for every $1 \%$ increase in FDI, import trade and export trade increase by $0.34 \%$ and $0.22 \%$ respectively. The import trade elasticity of FDI is greater than the export trade elasticity. It shows that China's FDI has promoted the net trade exports of Central Asia to China, which is conducive to the economic growth of Central Asia.

3. China has different degrees of influence on FDI's import and export trade in Central Asian countries. The elasticity of China's FDI to import trade and export trade in Kazakhstan is 0.41 and 0.35 , respectively. The import trade elasticity of FDI is greater than the export trade elasticity. It shows that China's FDI to Kazakhstan is mainly to drive imports, and to promote exports as a supplement. The elasticity of China's FDI in Uzbekistan to import trade and export trade is 0.20 and 0.26 , respectively. The import trade elasticity of FDI is smaller than the export trade elasticity. It shows that the import creation effect of Chinese FDI in Uzbekistan is smaller than the export creation effect. The elasticity of China's FDI in Kyrgyzstan to import trade and export trade is -0.67 and -0.16 , respectively, showing a trade substitution effect. The elasticity of China's FDI in Tajikistan to import trade and export trade is -0.45 and 0.16 , respectively, which is reflected in the import substitution effect and export creation effect. The elasticity of China's FDI in Turkmenistan to import trade and export trade failed the hypothesis test of the model. The possible reason is that China's FDI and export scale in Turkmenistan is relatively small, while the import scale is relatively large. There is no linear correlation between FDI and import and export trade.

4. In view of the creation effect of China's FDI import and export trade with Central Asian countries, China should strengthen economic and trade cooperation with Central Asian countries and expand the scale of FDI. The two sides should reduce trade barriers, expand investment areas, and provide favorable policy support for expanding the scale of FDI. For example, China should reduce the tax burden of enterprises' foreign investment and guide Chinese enterprises to invest in Central Asian countries. China should increase its direct investment in Kazakhstan and Uzbekistan. Kazakhstan and Uzbekistan have large populations and vast markets. Their export products are mainly resource products and agricultural products. China should make direct investment in their light industry and mineral resource development industries. Kazakhstan and Turkmenistan are the countries with a large scale and proportion of China's import and export trade in Central Asia. China's FDI to Kazakhstan and Turkmenistan will promote the export of Chinese mining machinery and equipment, and at the same time drive the import of energy. In addition, Kazakhstan and Turkmenistan have relatively high levels of economic development among Central Asian countries, with huge market potential, and relatively insufficient light industry development. The two countries should increase FDI investment in light industry.

\section{Acknowledgments}

The author is very grateful to his doctoral supervisor, Professor M. Amonboev. Dr. You Lijie and Teacher Ma Cuilin provided a lot of help for this article. Special thanks to the editors of this journal for their many valuable comments on the previous edition, which have improved its quality and content to its current state.

\section{References}

- Bedassa Tadesse, Michael Ryan (2004). Host market characteristics, FDI, and the FDI trade relationship. Journal of International Trade \& Economic Development, 13(2):199-229. CrossRef

- Jiang Wei, Fu Yuding (2014). The import trade effect of China's two-way FDI: impact mechanism and empirical analysis. International Economics and Trade Research, 30(6): 1527. 


\section{Zhang Lingzhi}

Research on Import and Export Trade Based on China's FDI to Central Asian Countries

- Kiyoshi Kojima (1987). Foreign Trade Theory. Zhou Baolian, translated. Tianjin: Nankai University Press: 442-444.

- Lai Shicheng, Zhong Wei (2011). An Empirical Study on the Relationship between Trade and FDI between China and ASEAN Countries. Southeast Asia, (7): 16-20.

- Qin Fangming, Zhang Limin, Bi Yanru (2012). From the perspective of investment, the regional economic cooperation between China and Central Asian countries. Development Research, (2): 1-5.

- Robert Alexander Mundll (1957). International Trade and Factor Mobility. American Economic Review, 47 (3):321-335.

- Shi Jinfang (2015). China's Central Asian Economic and Trade Strategy Thinking--Based on the Perspective of Strategic Game with Great Powers under the Framework of "New Silk Road". Macroeconomic Research, (9): 32-39.

- Wang Guoting, Ren Rongming (2015). On the influencing factors of China's direct investment in Central Asia: a comprehensive study based on the economic and institutional perspective. Science and Technology Management Research, 35(8): 180-184.

- Wang Haiyan (2015). Research on the Economic and Social Development Situation of Central Asian Countries from the Perspective of "One Belt and One Road". Journal of Xinjiang Normal University (Philosophy and Social Sciences Edition), 36(5): 78-86.

- Wang Qiuhong, Wang Cong (2014). Research on my country's export structure based on cluster analysis-take 13 provinces (autonomous regions) as examples. Journal of Management, 27(3): 44- 48.

- Xiang Benwu (2006). Research on the Trade Effect of Foreign Direct Investment--An Empirical Analysis Based on China's Experience. Journal of Zhongnan University of Economics and Law, (3): 9-15.

- Yang Dianzhong (2012). Industrial distribution of Chinese enterprises' direct investment in Central Asian countries and industry selection suggestions. Journal of Central University of Finance and Economics, (1): 66-71.

- Zhu Zhiming, Ding Haiyan, Chen Xiaolin (2015). "One Belt and One Road" China OFDI's impact on the economic growth of Central Asian countries. Journal of Hohai University (Philosophy and Social Sciences Edition), 17(5): $67-72$. 